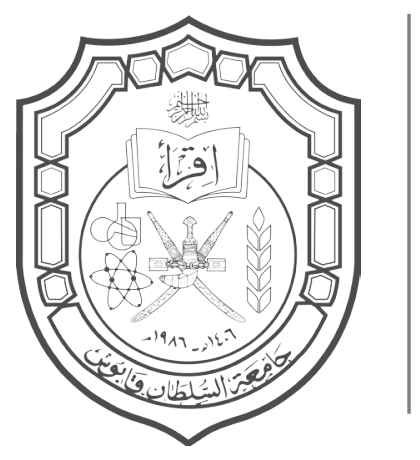

Cultural Aspects of Arabicisation: Past and Present

Musallam Al-Ma'ani 


\title{
Cultural Aspects of Arabicisation: Past and Present
}

\author{
Musallam Al-Ma'ani
}

\section{Abstract}

The aim of this article is to examine the cultural dimensions of arabicisation, past and present. The article traces the rise and fall of arabicisation and its ramifications for science, knowledge, research and education in and through Arabic.

Arabicisation has been at the heart of linguistic and cultural debate since the dawn of Islam, a debate intensified when the Arabs and their new religion came into contact with different civilizations and cultures. The rise of the Islamic empire in mediaeval times consolidated Arabic and Arab culture, attracting scholars from around the world to research different areas of science and knowledge through the medium of Arabic, which in turn became, and remained for centuries, the global donor language of knowledge and learning. With the decline of the Arab/Islamic empire, however, Arabic and Arab culture started to lose their world standing.

Today, Arabic and its culture occupy a marginal position when compared to other languages like English for instance. For different internal and external reasons, Arabic has lost its status as the major language of innovation and creative thinking. But this is not because it cannot handle the concepts of modern civilization or is unable to express them; rather the cultural position of Arabs seems to be the main reason. Instead of being the predominant language of science and technology, Arabic has been competed by other foreign languages in its own territories. The widespread use of European languages, the languages of the colonizing powers, has undermined its role.

Furthermore, the lack of pan-Arab policies on language planning has contributed to the emergence of different and often disparate models of arabicisation. Transformation in the objectives and scope of the process reflects the historical developments and decline of Arab culture from medieval times to the present day.

\section{Keywords:}

Arabicisation; Islam; Islamic empire;Arab culture; pan-Arab policies on language planning

ملخص ظل التعريب موضع نقاش وبحث منذ ظهورالإسلام، ومع الفتوحات الإسلامية احتك العرب مع حضارات وثقافات العالم آنذاك. ولقد عزز رقي الإمبراطورية الإسلامية في العصور الوسطى الثقافة العربية ولغتها الأمر الذي كان له الأثر في استقطاب العلماء

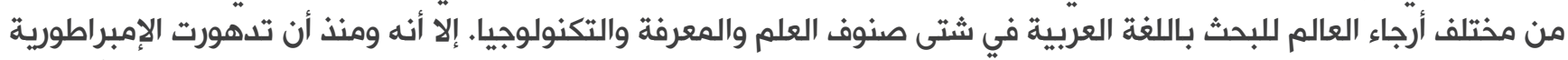

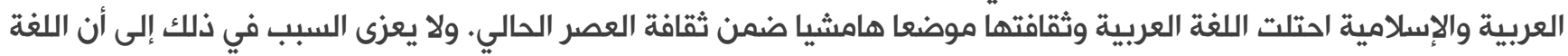

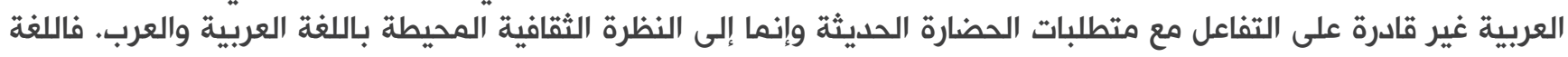

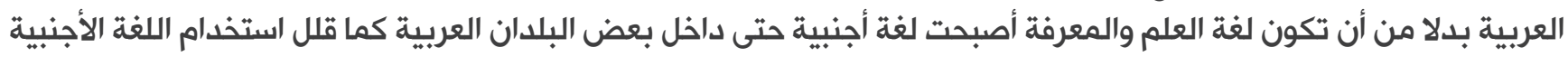

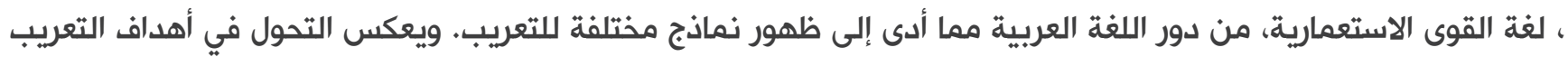
ومجالاته التطور في الثقافة العربية وتدهورها المستمر. لذا يهدف هذا البحث الى تسليط الضوء على الثىتاثير العنصر الثقافي في في في التعريب وأثره على مختلف مجالات العلم والمعرفة والبحث والتمبة والتعليم. 


\section{Introduction:}

The history of the young discipline of translation studies indicates that there has always been a link between translation and the rise and fall of cultures. This history also shows that when translation is supported as a social enterprise, its culture tends to develop and carve out for itself influence, be it national, regional or global. A perusal of the rise and fall of Arabic translation, including arabicisation, provides an insight into key moments of Arab cultural history.

Researchers cannot agree on when arabicisation was first introduced into Arabic, something that is partly explained by the fact that the term itself can be understood in three senses:

1. The use of Arabic as the language of thought, education and communication (Hashim, 1988:38).

2. The translation of sciences, arts and literature into Arabic. In this respect, the terms arabicisation and translation both represent the same notion (Al-Namla, 1992:11).

3. The transfer of a word or a term from a foreign language into Arabic with no changes being made except for changes to pronunciation to suit the sound system of Arabic (Badawi, 1973:25).

From these three definitions, it is clear that objectives are varied and cover a wide range of meanings but, in general, they all imply the widest possible use of Arabic in all fields including daily life communication.

When considering the arabicisation movement, it is perhaps necessary to look at the subject from two perspectives: (1) the mediaeval period when arabicisation was a source of cultural prestige and (2) the recent cultural image inflicted on arabicisation over the last few decades in which Arabic is no longer seen as central in modern global, or even, Arab culture.

\section{Arabicisation ... past}

The position of arabicisation in medieval times was a far cry from its present counterpart. It was closely related to the position Arab culture occupied at that time. Saleh (2006: 19) attributes this to the real Arab contributions which 'date back centuries [to] when the Arab-Islamic empire was at its zenith'. When Arabic was a major medium of knowledge and science, Arabs looked at arabicisation as one way of keeping abreast of other languages and cultures. This process involved both the domestication of foreign sciences through a massivetranslationmovementand a simultaneous and accompanying unprecedented volume of research and publication in Arabic. In Baghdad, bayt al-Hikma (The House of Wisdom) served as an academy, a library, a museum, an observatory and a translation bureau (cf. Hitti, 1952).

Remarkably, a language that was, until the advent of Islam, only a literary language with limited or no geopolitical influence, managed in a very short period to domesticate an array of alien sciences into Arabic.

Although these incoming sciences were new for the Arabs and the Islamic state, the clear planning and policies of most Umayyad and Abbasid Caliphs further expanded the boundaries of the Muslim state and contributed to the rapid establishment of a unique Arab/slamic cultural identity, supported by translation and arabicisation.

Mediaeval Arabs/Muslims faced considerable obstacles, among them how to teach these new areas of knowledge to their own people and how they should be arabicised. Here the term arabicised not only involves linguistic considerations, But it also covers the cultural assimilation of these imported sciences. History clearly shows that the Arabs succeeded in firmly putting their language and culture onto the world map. Arabic indeed remained superior and dominant in mediaeval times, prompting others, including Europeans, to adopt many of its aspects. For example, knowledge of Arabic astronomy was brought to England and Scientific texts from Arabic into Latin were translated in the north of Spain (cf. Pym 2001). But how did the Arabs manage this? 
Translation, in mediaeval history, served as an essential means of communication between Arabs and other nations and cultures for reasons social, scientific, technical, religious and economic. Translation was seen as 'one of the main means through which texts of one culture are made available in another' (Faiq, 2006:57). It was a process necessitating not only knowledge of a foreign language but also a thorough understanding of source cultures. The translation of a scientific text, for example, required great accuracy and knowledge of the scientific and cultural setting in which that particular material had originated.

Mediaeval Arabic translation became closely linked with the cultural reality of arabicisation, creating a unique context characterized by:

1. The supremacy of Arabic and Arab culture;

2. The introduction of new scientific and technical terms through various techniques and the ready borrowing or lending of such terms;

3. The consolidation of the position of Arabic as both an international language and as a medium of science and technology; while it remained as the primary language of high culture throughout the Islamic world (or Islamic culture-zone) used not only by Muslims but also non-Muslims for serious cultural endeavours in this part of the world.

4. The provision of financial resources to further the process of arabicisation by richly rewarding works of translation (history has it that the Caliph al-Ma'amun used to pay in gold, matching the weight of translated books), and

5. The nurturing of a culture supportive of research in various disciplines.

\section{Arabicisation ... present}

Since the 19th century, and when many Arab countries gained their independence, an intellectual movement has arisen in the Arab world that supports arabicisation as well as the translation of mainly scientific and technological works into Arabic. Because the Arab world had been isolated for so long from the mainstream of modern science and technology, the Arabs' status and language had weakened. Furthermore, the colonial and postcolonial era, with all its negative aspects, has nurtured a reliance on foreign languages for scientific and social prestige reasons among Arabs. As a result, Arabic faces threats from foreign languages, undermining its role in embracing, for instance, modern sciences and their related terminologies. There is also a lack of political will necessary to protect Arabic in this regard as well as a lack of resources necessary to further the process of research and arabicisation.

The resulting situation can be characterized

by the lack of Arabic technical terms and updated technical references and dictionaries to account for many new inventions and their associated terms. In addition, an influx of foreign terms has become a common feature not only in written documents but also in daily conversation amongst Arabs themselves and in Arab countries [for further examples on the use of foreign terms in Arabic see Qunaybi (1991)]. The inertia within the Arab world has made it lag behind other cultures and languages, thus clearly making it incapable of quickly embracing and assimilating new fields of science and technology.

However, a renaissance, albeit relatively weak and insignificant compared to its medieval counterpart, has prompted Arabs to focus on the issue of arabicisation (Al-Mutawwa, 1989:8). As a result of this trivial awakening, two models of arabicisation have evolved:

1. The Arab Mashria (East Arab World) model, which prevails in Egypt, Sudan, Syria, Jordan and other Gulf states, is characterized by the translation of scientific and technical terminology. That is, arabicisation involves finding Arabic equivalents for foreign words/ terms in Arabic. Here, the focus of arabicisation is not on the use of language as Arabic within this model's zone is used in all walks of daily life but rather targets the transfer of scientific and technical terms into Arabic

2. The Arab Maghrib (West Arab World) model, 
which prevails in Tunisia, Algeria, Morocco and Mauritania, attempts to restore the use of Arabic in all activities of daily community life. Arabicisation can be seen as an attempt to implement efficient educational policies including:

1) The teaching of Arabic at a certain stage of education, (a system adopted in Morocco);

2) The teaching of Arabic in specific sections/ fields of knowledge such as sciences or mathematics, and

3) The use of Arabic at all education levels, leading to foreign languages, particularly English and French, losing their primacy in these circumstances.

There are differences not only between the Arab Mashriq and Maghrib models, but also between the countries of each model depending on the way arabicisation is approached. Yusuf (1982) attributes this to historical reasons which have revived Arabic and accelerated arabicisation in some Arab countries more than others. Within the Mashriq model, the use of Arabic in daily life activities, in public documents and events and in mass communications, is a common feature; the focus of this model is on the problems of terminology which can be seen as the main obstacle towards arabicisation and the situation dictates a search for equivalent scientific and technicalterminology. Accordingto Ahmed (1986: 42), this model can, in general, be characterized by two main objectives: 'the introduction of new scientific and technical terms into Arabic and the borrowing of foreign terminology' [my translation from Arabic].

In the Arab Maghrib model, arabicisation covers all aspects of daily life because it is seen not only as a technical issue but also as a political one (Ammar \& Al-Khuri, 1996). The reason may be that the Arab Maghrib countries were under the influence of foreign languages and cultures for longer periods than those in the Arab Mashriq. Abdulaziz (1990) considers this a direct result of colonial attempts to weaken the position of Arabic by encouraging the use of foreign languages. This situation has called for more efforts to be exerted to deal with issues of arabicisation, represented by specific moves to handle this issue within individual countries and by collective efforts at either regional or pan-Arab levels.

With regard to collective Arab efforts, the first arabicisation conference was held in 1961 and aimed at coordinating the efforts of Arab countries to standardize technical and scientific terms. This is evident in the objectives of the Bureau for the Co-ordination of Arabicisation in the Arab World based in Rabat, Morocco. To tackle various aspects of arabicisation and the standardization of terminology in the Arab world, the Bureau publishes a specialized magazine (allisaan al-'arabii) and organizes regular seminars and conferences. The Bureau also runs courses on the general theory of terminology. Another example of collective effort was an attempt to unify the language academies in 1956, but this did not become reality until 1982 when Syria, Iraa and Egypt agreed to establish the Association of Arab Language Academies.

Individual efforts have focused particularly on the issue of terminology, especially that of a scientific and technical nature. To this end, many Arab countries have attempted to set up academies which are "scholarly language institutions set up to serve the [Arabic] language and in which scholars meet to promote the language, sciences, arts, etc" (Bal'iid, 2002:13). In other words, these academies are specialized bodies charged with a number of tasks, including the introduction of new scientific and technical terms, the production of specialized dictionaries and glossaries and the revival of Arabic literature (ibid: 16). Consequently, language academies have been set up in Syria, Egypt, Iraq, Jordan, Sudan, etc. The oldest is the Arabic Language Academy of Damascus, which was set up in 1919. Other countries took similar steps at a later time in the last century with the aim of dealing with matters related to arabicisation especially in the area of education (Isam Addeen, 1986). 
But despite these efforts, the process of arabicisation still faces formidable obstacles as a result of the cultural image associated with Arabs and their language. There are very few attempts to change this image and even when these occur, translations from Arabic literature into Western languages are in reality more attempts 'to account for, or recount, the asymmetry and inequality of relations between peoples, races and languages' (Niranjana, 1992:1). Faiq (2007:6) comments in this regard 'the discourse of translation from Arabic still haunts any fair intercultural exchange. It seems the West has already decided that the Arab and Islamic cultures have nothing of substance to offer modern history. Translation from it ... remains prisoner of nineteenth century images and representations'.

Within this cultural context, the problems of technical translation will remain since the availability of references and terminology hinges upon progress made in arabicisation and Arab ability to carry out research that is both in Arabic and internationally recognized. Communication between Arab countries is a further obstacle to arabicisation, which cannot bear fruit, on a panArab level, unless a general policy of scientific and technical translation is implemented. This is because each Arab country has its own translations of foreign terms, which creates confusion among Arab readers and foreign students learning Arabic (Faiq, 2000). Such a diversity of efforts can be counter-productive since each country usually ends up using its own terms, which are influenced by social, political and post-colonial conditions. A study carried out by Al-Ma'ani (2000) shows the discrepancies in the use of technical terms between different Arab countries. Al-Ma'ani (2000:169) gives an example of military terms used by Sultan's Armed Forces (SAF) which are different from those used by other Arab countries. For example, the word فني is used in Oman as an equivalent to technician. However, the Arabic term used in other Arab countries is تقني . If this latter word is used in SAF, an Omani serviceman would not be able to link it to its intended meaning because within SAF context, تقني means technological. Similarly, helicopter means in SAF context طائرة عمودية whereas in other Arab states سمتية ، عمودية Other equivalents are used such as مروحية.

In addition, the dissemination of terms is inadequate as many do not gain currency - a further reason for the duplication of efforts in the Arab world.

In the field of education, most researchers concerned with arabicisation agree that the educational system in the Arab world suffers from severe defects in Arabic teaching (AlQahtani, 2002). In addition, the problems of arabicising higher education remain the same. Although educational policies in most Arab universities stipulate that Arabic is the medium of instruction, foreign languages are commonly used in science colleges. A valid reason is that because almost all research and publications are carried out in English, the use of Arabic will be counter-productive without a parallel movement in translation and research to keep pace with the latest developments in science and technology. Al-Qahtani, (2002) further indicates that the use of Arabic in higher education involves such problems as the rarity of Arabic scientific materials, the lack of specialist references, and the lack of unified Arabic terms and abbreviations, which are all problems arabicisation does not seem able to solve.

\section{Cultural deficit of Arabicisation}

One of the realities, not yet fully appreciated by many Arabs when handling the issue of arabicisation, is a failure to realize that the gap between the Arab world and the West in particular is not only technical or technological but also cultural. In mediaeval times, Arabic occupied a central and prestigious position. The power and legitimacy underlying the cultural image gave Arabic a strong position, helping the language of Islam to gradually take over the ground of many civilizations which could not withstand the influence of the powerful Islamic state. But how 
did this help arabicisation?

The Arabic language is now in a better position than that it held during the early Arab state in mediaeval times for a variety of reasons:

1. Arabic then was a language of poetry with limited influence.

2. Mediaeval sciences were completely new not only to Arabic but also to the Arabs themselves, hence a dialogue with other peoples of distant cultures was established, convincing them either to migrate to the centre of Islamic state or convert to Islam. Al-Ma'amun, for instance, 'encouraged and imported men of learning regardless of race or religion' (Nutting, 1964:125).

3. Arabic scientific terms in mediaeval times were limited if not rare, so to find new terms was a very difficult task especially in a society where these sciences had not originated.

4. The concept of modern school education did not exist, and even where schooling existed it was dominated by Islamic religious studies. So to divert that attention of the Muslim state to other streams which were not purely religious must have been very difficult.

5. Compared to modern information technology tools, the means of contact and communication were limited in mediaeval times, thus the dissemination and standardization of terminology could not have been very successful and effective. Yet somehow it worked!

It was the historically unprecedented Arabic translation movement which was central to developing sciences and domesticating alien disciplines beyond their previous Greek and Indian confines. Adopting Lefevere's (1992) view, translation was not just 'a window opened on another world', but rather a channel through which Arabic was able to penetrate other cultures and challenge them. Translation within medieval Arab translation was not seen as mere transfer of knowledge but as both a translation and scholarly movement, in the sense that the task was not just to translate but also to read and further research the areas from which translation was carried out. Translation into Arabic was thus only the starting point for profound intellectual developments within Arab/Islamic state. But translation requires a necessary cultural environment within which to flourish and serve society. As Saleh (2005, p. 31) writes "even if translation manages to overcome its problems, it cannot, on its own, serve as the panacea for Arab cultural inertia".

Nowadays, some cultures try to 'subvert' others which do not occupy a prestigious status. This subversion drives the subverted cultures, including the Arab one, to cast doubts not only on their technical and technological potential but also on their values, customs, beliefs, and world view. So, when Arab intellectuals say that Arabic cannot be used as a medium of instruction in university education and particularly in science colleges, it is really an indirect acknowledgement of an inadequacy to handle scientific material in one's own language and in one's own culture. It is true that the dominance of English in science and technology is acknowledged not only in the Arab world but also in other countries worldwide. And even in cases where English is not used as a medium of instruction in education, scientific publications are still made in English along with, in some cases, the native language like in Russia for instance (cf. Kryuchkova, 2001). However, the use of the foreign language in these countries cannot be compared to the Arab situation. In Japan, for instance, English is not seen as a threat because as a result of enormous works of translating foreign scientific material over a century, "Japanese people could develop their own technology relying on their own mother tongue" (Inoue, 2001:447-8). The Arab situation is totally different; some Arab countries have long been colonized by various Western nations. If we take the Arab Maghrib countries, Arabicisation in these countries is undertaken against a background in which French colonial educational and cultural policies made French the dominant language of high culture in these countries and was introduced as a colonial and commercial language. 
However, during mediaeval times, translators were able to efface what Venuti (1995) called the 'second-order status' of translation. Translators had total freedom to express their thought and so their translations were often viewed as original and transparent rewritings. Translation, through such an approach, made what was not Arabic arabicised through what Faiq (2007: 56) calls 'gist translation'. Through this approach, arabicisation was achieved by the additions and omissions the translators made to the source texts. Translation was not an end in itself, but a step for further development and research since 'the need for translation from Greek and from other languages diminished as Arab scholars started to produce their own research' (ibid.: 55).

Whereas in medieval times the focus was placed on ways that might bring in research and assert the contribution of Arabic to mankind, the situation today seems to take an opposite direction. If we take, for instance, the Arab Maghrib model, arabicisation remains a battle against the use of French and the influence of its culture. Thus, instead of playing its real role in scientific and technical areas, the efforts of arabicisation have been directed to retaining the status of the native language itself and preserving national cultural identity (Al-Sayyadi, 1982).

\section{Conclusion}

It is the marginal position of Arab culture in today's world that leaves Arabs behind technologically. This not only affects scientific and technological fields but also other areas of scholarship for which Arabic is known, such as literature. The state of Arabic today is almost similar to that of other languages and cultures which were under colonial influence for a long period of time, although Arabic had a glorious past. It is most likely that the prevailing cultural inadequacy of the Arab world hinders progress in arabicisation in all areas of knowledge. 


\section{References:}

- Abdulaziz, M. 1990. at-ta'riib fil qadiim wal Hadiith. daar alfikir al 'arabi. Beirut.

- Ahmed, N. 1986. at-ta'riib wal qawmiyyah al 'arabiyyah. Centre for Arab Unity Studies. Beirut.

- Al-Ma'ani, M. 2000. The Problematics of Technical Translation into Arabic. Unpublished Pha thesis. University of Salford. UK.

- Al-Mutawwa, N. 1989. aafaaq al tarjamah wat ta'riib. In 'alam al fikir, No. 4, pp5-14.

- Al-Namla, A. 1992. maraakiz al tarjamah al qadiimah 'ind al muslimiin. National King Fahad Library. Riyadh.

- Al-Qahtani, S. 2002. at-ta'riib wa nadhriyyat al takhTiiT al lughawii. Centre for Arab Unity Studies. Beirut.

- Al-Sayyadi, M. 1982. at-ta'riib wa tansiiquhuu fil waTan al 'arabi. Centre for Arab Unity Studies. Beirut.

- Ammar, S. \& Al-Khuri, Sh. 1996. at-ta'riib fil waTan al 'arabi, waaqi'uhu wa mustaqbalahu. Alesco. Tunis.

- Badawi, A. 1973. Mustawayaat al'arabiyyah almu'aaSirah fi misr. daar al ma'aarif bimisr. Cairo.

- Bal'iid, S. 2002. juhuud al majaami' wal muasasaat al thaqaafiyya al'arabiyyah fii taraiyat allugha al'arabiyyah. In majallat majma' al lughah al'arabiyyah, No. 23, pp. 11-30.

- Faiq, S. 2000. Arabic Translation: A Glorious Past but a Meek Present. In M. Rose (Ed.). Trans/ation Perspectives IX: Beyond the Western Tradition (pp. 30-42). State University of New York at Binghamton. Binghamton.

- 2006. Cultural Dislocation through Translation. In S. Faiq (Ed.). Trans/ation, Representation and Identity in Intercultural Communication. pp. 19-32. San Antonio, TX. Trinity University.

- 2007. Transl-lated: Translation and Cultural Manipulation. Rowan \& Littlefield. Lanham \& Oxford.

- Hashim, A. 1988. mafhuum atta'riib. In majallat majma' al lughah al'arabiyyah, No. 10, pp 27 43.

- Hitti, P. 1952. History of the Arabs. Macmillan. London.

- Inoue, F. 2001. English as a Language of Science in Japan. From Corpus Planning to Status Planning. In U. Ammon (Ed.). The Dominance of English as a Language of Science: Effects on other Languages and Language Communities (pp. 447-470). Walter de Gruyter. Berlin. 
- Isam Addeen, A. 1986. Harakaat al tarjamah fii miSr fil qarn al 'ishriin. Al hay ah al miSriyyah al 'aamah lilkitaab. Cairo.

- Kryuchkova, T. 2001. English as a Language of Science in Russia. In U. Ammon (Ed.). The Dominance of English as a Language of Science: Effects on other Languages and Language Communities (pp. 405-424). Walter de Gruyter. Berlin.

- Lefevere, A. 1992. Trans/ation/History/Culture. Routledge: London.

- Niranjana, T. 1992. Siting Trans/ation: History, post-structuralism and the colonial context. University of California Press: Berkeley.

- Nutting, A. 1964. The Arabs. Mentor. New York.

- Qunaybi, H. 1991. Diraasaat fii ta’Siil almu'arrabat wal muSTlahaat. Daar aljiil. Beirut.

- Pym, A. 2001. Spanish Tradition. In M. Baker (Ed.). Routledge Encyclopedia of Translation Studies. pp. 552-560 . Routledge, London and New York.

- Saleh, S. 2006. Culture and the Problematics of Arabic Translation. In S. Faiq (Ed.). Trans/ation, Representation and Identity in Intercultural Communication (pp. 19-32). Trinity University. San Antonio. TX

- Venuti, L. 1995. The Trans/ator's Invisibility. Routledge. London.

- Yusuf, H. 1982. at-ta'riib fil aqTaar al 'arabiyyah dhata al awDaa' al khaaSah. In M. Al-Sayyadi (Ed.) al ta'riib wa tansiiquhu fil waTan al 'arabi (pp 309-324). Centre for Arab Unity Studies. Beirut. 